\title{
Mice serve as paratenic hosts for the transmission of Caryospora duszynskii (Apicomplexa: Eimeriidae) between snakes of the genus Elaphe
}

\author{
David Modrý ${ }^{1,2}$, Jan R. Šlapeta ${ }^{1,2,3}$ and Břetislav Koudela ${ }^{1,2}$ \\ ${ }^{1}$ Department of Parasitology, University of Veterinary and Pharmaceutical Sciences Brno, Palackého 1-3, 61242 Brno, Czech \\ Republic; \\ ${ }^{2}$ Institute of Parasitology, Academy of Sciences of the Czech Republic, Branišovská 31, 37005 České Budějovice, Czech \\ Republic; \\ ${ }^{3}$ Present address: Unité d'Ecologie, Systématique \& Evolution, CNRS UMR 8079, Université Paris-Sud, Orsay, France
}

Key words: Coccidia, Eimeriidae, Caryospora duszynskii, transmission, paratenic host

\begin{abstract}
Caryospora duszynskii Upton, Current et Barnard, 1984 was successfully transmitted to snakes of the genus Elaphe by feeding them previously infected mice. Fifty thousand oocysts were orally administered to two mouse strains, BALB/c and Crl:CD-1(ICR)BR, which were subsequently fed to captive-born coccidia-free Elaphe guttata (L.) in two respective independent experiments. Both E. guttata expelled C. duszynskii oocysts in their faeces, beginning on day 18 and 26 post infection (p.i.) and shed oocysts continuously through the end of the experiment, day 230 and 135 p.i., respectively. There were no parasitic stages or lesions in mice, as revealed by histological examination. Experiments proved that rodents serve as paratenic hosts for $C$. duszynskii. In summary we discuss the life-cycle strategies of Caryospora spp. in reptiles and present three general modes of their development.
\end{abstract}

Coccidian parasites of the genus Caryospora Léger, 1904 (Apicomplexa: Eimeriidae) are widely distributed among reptiles and raptorial birds. Although the life cycle of most of the described species remains unknown, most are presumed to be monoxenous (Modrý 1999). To date, heteroxenous life cycles have been documented in three species of the genus: Caryospora bubonis Cawthorn et Stockdale, 1981 from the great horned owl Bubo virginianus Gmelin, C. bigenetica Wacha et Christiansen, 1982 from North American rattlesnakes Crotallus spp., and C. simplex Léger, 1904 from European vipers Vipera spp. While details of the C. bubonis life cycle remain unstudied, the life cycles of the two latter species infecting viperid snakes are experi-mentally and morphologically well described. Both species, $C$. simplex and $C$. bigenetica, are transmitted via mammalian hosts infected with sporulated oocysts. Asexual and sexual division followed by sporogony and excystation occurs predominantly in the connective tissue of the nose, tongue and cheeks and the scrotum. The sporozoites that excyst in situ from the tissue cysts enter host cells and induce their transformation to unizoic caryocysts (Cawthorn and Stockdale 1982, Wacha and Christiansen 1982, Upton and Barnard 1988).

To study the above mentioned complex life cycle of Caryospora spp., Koudela et al. (2000) have used Severe Combined Immunodeficient (SCID) mice. The heteroxenous mode of the development using SCID mice was confirmed for Caryospora spp. from snakes of the Viperidae, but was not confirmed for reptileoriginated Caryospora spp., including C. duszynskii Upton, Current et Barnard, 1984 (Koudela et al. 2000). In addition to the heteroxenous development, Volf et al. (2001) described the experimental transmission of $C$. kutzeri Böer, 1982 between kestrels using previously infected mice and proposed that rodents serve as paratenic hosts for this species. The present study examined the role of rodents in the life cycle of $C$. duszynskii, a species widely distributed among North American colubrid snakes (Upton et al. 1984a, McAllister et al. 1995).

\section{MATERIALS AND METHODS}

The isolate of $C$. duszynskii was harvested from three corn snakes, Elaphe g. guttata (L.) (Serpentes: Colubridae), caught in the wild and freshly imported from Hillsborough County, Florida, USA by a private herpeto-keeper. The animals were caged separately in quarantine and coprological examination revealed moderate numbers of unsporulated oocysts in two of the snakes. After sporulation in $2.5 \%$ potassium dichromate $(5$ days at $22^{\circ} \mathrm{C}$ ), oocysts were purified and concentrated through flotation in a modified Sheather's sugar solution, then measured and photographed.

In Experiment 1 (Exp. 1), a three-month-old captive-born coccidia-free juvenile rat snake, Elaphe obsoleta Say, 1823 was orally inoculated with 10,000 oocysts using a stomach tube. Two additional snakes of the same origin served as uninfected controls. Oocysts were detected in faeces from 24 to 65 days post infection (p.i.) and used for the next experiments. Oocysts were concentrated and stored as described above. 
Table 1. Schematic representation of experiments of Caryospora duszynskii transmission between snakes, Elaphe guttata and E. obsoleta, and mice.

\begin{tabular}{|c|l|l|l|l|}
\hline Exp. No. & \multicolumn{1}{|c|}{ Donor host } & \multicolumn{1}{|c|}{ Dose } & \multicolumn{1}{|c|}{ Recipient host } & \multicolumn{1}{|c|}{ Result } \\
\hline 1 & E. guttata & 10,000 oocysts & E. obsoleta & Oocysts expelled 24-65 days p.i. \\
2 & E. obsoleta (Exp. 1) & 50,000 oocysts & Crl:CD-1(ICR)BR mice & No histological lesions \\
3 & Crl:CD-1(ICR)BR mice (Exp. 2) & 3 mice at day 0, 12, 22 p.i. & E. guttata & Oocysts expelled 26-135 days p.i. \\
4 & E. obsoleta (Exp. 1) & 50,000 oocysts & BALB/c mice & No histological lesions \\
5 & BALB/c mice (Exp. 4) & 3 mice at day 0, 21 p.i. & E. guttata & Oocysts expelled 18-230 days p.i. \\
\hline
\end{tabular}

In Experiment 2 (Exp. 2), 50,000 purified oocysts from Exp. 1 were orally administered to $5 \mathrm{Crl}$ :CD-1(ICR)BR mice (Anlab Brno, Czech Republic). Mice were housed in standard plastic cages with wooden shavings for bedding and were fed a standard rodent diet. Cages were completely cleaned daily to exclude the possibility of the passive transmission of caryosporan oocysts.

In Experiment 3 (Exp. 3), 10 days after the infection, 3 mice from Exp. 2 were subsequently fed to a subadult, captive-born coccidia-free corn snake, Elaphe guttata on day 0, 12 and 22. The faeces of the experimental snake were collected and examined irregularly based on its feeding habit.

In Experiment 4 (Exp. 4), 50,000 purified oocysts from Exp. 1 were orally administered to BALB/c mice (Anlab Brno, Czech Republic) and treated as in Exp. 2. Two of these mice were killed at days p.i. 14 and 35 and used for histological examination and Exp. 5.

In Experiment 5 (Exp. 5), 2 mice from Exp. 4 were subsequently fed to an adult E. guttata instead of the subadult (Exp. 3 ), captive-born coccidia-free corn snake, E. guttata on day 0 and 21 and treated as in Exp. 3. All experiments are summarized in Table 1.

The Exp. 4-5 were conducted 6 months after the completion of the previous experiments (Exp. 2-3). In Exp. 3 and 5, two other corn snakes were kept under the same conditions and served as uninfected controls. For histological examination of $\mathrm{Crl}: \mathrm{CD}-1$ (ICR)BR and $\mathrm{BALB} / \mathrm{c}$ mice, the following organs and tissues were collected and fixed in $10 \%$ buffered formalin: oesophagus, stomach, duodenum, jejunum, ileum, caecum, rectum, lung, liver, kidney, spleen, mesenteric lymph nodes, tongue, hearth, diaphragm, muscles of the abdominal wall, brachial muscles (m. triceps brachii), thigh muscles (m. quadriceps femoris), masseters, upper cheek, eyelid, nose, foot pad, external genitalia and brain. Fixed tissues were processed by standard histological methods; paraffin sections were stained with haematoxylin and eosin (H\&E) and PAS and examined by light microscopy.

\section{RESULTS}

Elaphe obsoleta inoculated with $C$. duszynskii oocysts in Exp. 1 shed unsporulated oocysts by day 24 p.i. The morphological characters of the sporulated oocysts were in accordance to the original description of $C$. duszynskii (Upton et al. 1984a). Neither Crl:CD1(ICR)BR nor BALB/c mice inoculated (Exp. 2 and 4) with oocysts of $C$. duszynskii (Exp. 1) exhibited clinical signs of disease. Histological examination of the inoculated experimental mice did not reveal the presence of coccidian developmental stages or pathological changes.

Snakes in Exp. 3 shed oocysts from day 26 after feeding of the first experimental Crl:CD-1(ICR)BR mice and continued to shed oocysts until the end of the experiment (day 135). Similarly, the snake in Exp. 5 started to shed oocysts on day 18 after being fed the first inoculated BALB/c mice and a high number of oocysts was detected in the faeces up to the end of the experiment (day 230).

The results of both Exp. 3 and 5 demonstrate the possibility of an indirect transmission of $C$. duszynskii between corn snakes (Elaphe spp.) by rodents. Both of the E. guttata that were fed previously-infected mice shed C. duszynskii oocysts in their faeces. Follow-up morpho-logical examination of the sporulated oocysts did not reveal any differences from the original isolate (Exp. 1) of the oocysts isolated in Exp. 3 and 5.

\section{DISCUSSION}

Caryospora duszynskii, the only experimentally studied Caryospora species from colubrids, has a low host specificity, thus a relatively wide host spectrum, including three genera of North American colubrid snakes (Upton et al. 1984a, McAllister et al. 1995). The results of the present experiments demonstrated the experimental direct transmission of $C$. duszynskii from Elaphe guttata to Elaphe obsoleta, two closely related corn snakes. Importantly, the indirect transmission of $C$. duszynskii by rodents was demonstrated. Various rodent species serve as the common prey of colubrid snakes of the genus Elaphe in natural conditions (e.g. Green 1997) and could, therefore, play an important role in the transmission of $C$. duszynskii. The described indirect transmission route of $C$. duszynskii represents an alternative to direct transmission. The absence of clinical and pathological signs in the infected mice and, the failure to detect developmental stages in various organs of examined mice, suggest that $C$. duszynskii does not undergo any division in mammalian tissues. Rodents should therefore be classified as typical paratenic hosts in this system. Similar development has been shown in Isospora spp. parasitizing carnivorous mammals (Lindsay and Blagburn 1994). 
Mode 1

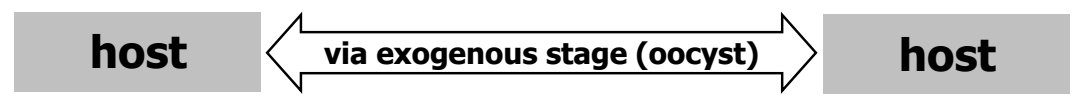

\section{Mode 2}
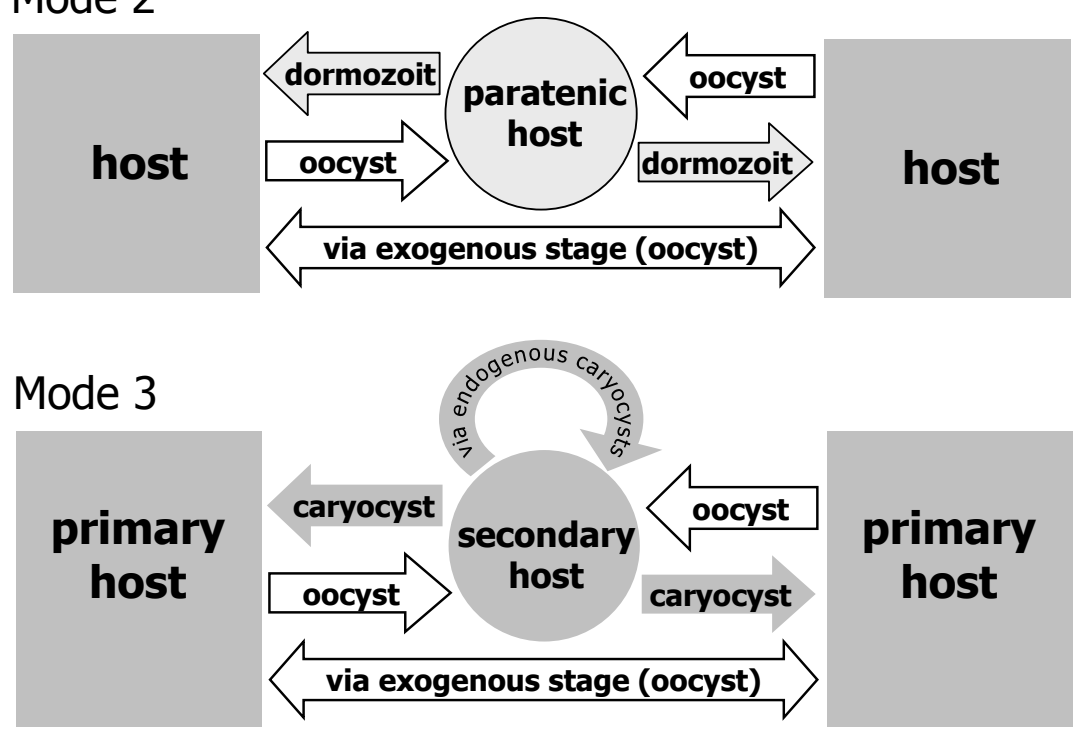

Fig. 1. Diagrammatic presentation of the three suggested general modes of the life cycle of Caryospora spp. Mode 1: Direct monoxenous development. Mode 2: Indirect monoxenous development with an alternative route involving a rodent paratenic host. Mode 3: Complex facultatively heteroxenous development involving an alternative to complex development in mammalian secondary host.

Previously, Lindsay et al. (1988) demonstrated the ability of excysted sporozoites of $C$. duszynskii to enter mammalian foetal lung cells in cell culture and to form only unizoic caryocyst-like formations. This observation further confirms the ability of $C$. duszynskii to survive in mammalian paratenic hosts. The absence of clinical signs in SCID mice, which were shown to be an optimal model for studying reptilian Caryospora which multiplicate in secondary hosts (Koudela et al. 2000), further supports presented results.

The presented results of paratenic hosts in the life cycle of $C$. duszynskii have further consequences for the potential survival of this parasite in the wild. Although the occurrence of development strategies other than monoxenous in Caryospora under natural conditions needs confirmation, the ability of several heteroxenous Sarcocystis spp. to cycle between snakes and their rodent prey (Odening 1998) suggests that development, or at least survival in the prey organism, enhances the ability of coccidia to be transmitted from one definitive host to another. Monoxenous development is generally thought to precede the more complex heteroxenous development. Various authors (see Barta 1989) suggested that heteroxenous development occurred as a reaction to certain behavioural changes in the definitive host, which threatened the successful transmission of the parasite. However, this may not always be the case. The coincidence of monoxenous (e.g. Eimeria) and obligatory heteroxenous (e.g. Sarcocystis) coccidia in snakes and co-occurrence of monoxenous and heteroxenous modes of transmission in some caryosporan coccidia can be explained simply as a result of maximal opportunism of these parasites.

The species of the coccidian genus Caryospora occurring in reptiles have documented a great variety of life-cycle strategies. To review the available information about the transmission routes, three distinct modes are detailed in Fig. 1.

(1) Direct monoxenous mode: Strictly monoxenous development is expected in Caryospora spp. from chelonian, saurian and ophidian hosts that apparently do not feed on vertebrate prey; this mode of development is also probable in several other species from snakes.

(2) Indirect monoxenous mode: C. duszynskii, and possibly other Caryospora species from rodent-eating snakes, are able to use rodents as paratenic hosts without any further multiplication in their tissues. This mode of transmission corresponds to that described by Cawthorn and Stockdale (1982) and Volf et al. (2001) in Caryospora spp. from owls (C. bubonis) and kestrels (C. kutzeri).

(3) Complex facultatively heteroxenous mode: Caryosporan coccidia that parasitize viperid snakes undergo complex development in mammals (so-called 
secondary hosts) including tissue gamogony. These species were also documented to be transmitted by cannibalism between various secondary hosts (Upton et al. 1984b, Upton et al. 1985, Upton and Barnard 1988, Upton and Sundermann 1990, Koudela et al. 2000). The "heteroxenous" species/isolates of Caryospora falling into mode " 3 " have identical or very similar oocyst morphology and parasitize viperid snakes in Africa, Europe, Asia and America (Koudela et al. 2000). We can assume that Caryospora spp. in vipers have a single origin, forming a monophyletic clade that co-evolved with its viperine hosts.

The flexibility of the life cycle in apicomplexan parasites has been recently documented using rDNA molecular data, suggesting a close and shared evolutionary history of Caryospora bigenetica and Lankesterella minima, allying Caryospora spp. into the Lankesterellidae rather than the traditional Eimeriidae
(Barta et al. 2001). However, many Caryospora spp. are monoxenous and the unique combination of endogenous development of facultatively heteroxenous Caryospora spp. is limited only to species parasitizing snakes of the Viperidae so far (Koudela et al. 2000). Heteroxenous development of various groups of coccidia evidently has arisen repeatedly (Barta 1989) and it is probable that the similarities in life-cycle strategies between some Caryospora and Lankesterella spp. are examples of analogy rather than homology.

Acknowledgements. We thank Veronika Schacherlová for preparation of histological sections and Monika Kadlecová for care of rodents. This study was supported by the Grant Agency of the Czech Republic (grants nos. 524/00/P015 and $524 / 03 / D 104)$ and the research project of the Institute of Parasitology, Academy of Sciences of the Czech Republic (research project no. Z60220518).

\section{REFERENCES}

BARTA J.R. 1989: Phylogenetic analysis of the class Sporozoea (phylum Apicomplexa Levine, 1970): evidence for the independent evolution of heteroxenous life cycle. J. Parasitol. 75: 195-206.

BARTA J.R., MARTIN D.S., CARRENO R.A., SIDDALL M.E., PROFOUS-JUCHELKA H., HOZZA M., POWLES A.A., SUNDERMANN C.A. 2001: Molecular phylogeny of the other tissue coccidia: Lankesterella and Caryospora. J. Parasitol. 87: 121-127.

CAWTHORN R.J., STOCKDALE P.H.G. 1982: The developmental cycle of Caryospora bubonis Cawthorn and Stockdale 1981 (Protozoa, Eimeriidae) in the great horned owl, Bubo virginianus (Gmelin). Can. J. Zool. 60: 152157.

GREEN H.W. 1997: Snakes: The Evolution of Mystery in Nature. University of California Press, Berkeley, Los Angeles, California, $351 \mathrm{pp}$.

KOUDELA B., MODRÝ D., VOLF J., ŠLAPETA J.R. 2000: SCID mice as a tool for evaluation of heteroxenous life cycle pattern of Caryospora (Apicomplexa: Eimeriidae) species. Vet. Parasitol. 92: 191-198.

LINDSAY D.S., BLAGBURN B.L. 1994: Biology of mammalian Isospora. Parasitol. Today 10: 215-220.

LINDSAY D.S., SUNDERMANN C.A., BLAGBURN B.L. 1988: Caryocyst-like host cell formation by Caryospora duszynskii (Apicomplexa: Eimeriidae) in human fetal lung cell culture. J. Protozool. 35: 32-33.

MODRÝ D. 1999: The Biology and Pathogenicity of Caryosporan Coccidia. PhD Thesis, University of Veterinary and Pharmaceutical Sciences, Brno, $52 \mathrm{pp}$.

McALLISTER C.T., UPTON S.J., TRAUTH S.E., DIXON J.R. 1995: Coccidian parasites (Apicomplexa) from snakes in the south-central and southwestern United States - new host and geographic records. J. Parasitol. 81: 6368.

ODENING K. 1998: The present state of species-systematics in Sarcocystis Lankester, 1882 (Protista, Sporozoa, Coccidia). Syst. Parasitol. 41: 209-233.

UPTON S.J., BARNARD S.M. 1988: Development of Caryospora bigenetica (Apicomplexa: Eimeriorina) in experimentally infected mice. Int. J. Parasitol. 18: 15-20.

UPTON S.J., CURRENT W.L., BARNARD S.M. 1984a: A new species of Caryospora (Apicomplexa: Eimeriorina) from Elaphe spp. (Serpentes: Colubridae) of the southeastern and central United States. Trans. Am. Microsc. Soc. 103: 240-244.

UPTON S.J., CURRENT W.L., ERNST J.V., BARNARD S.M. 1984b: Extraintestinal development of Caryospora simplex (Apicomplexa: Eimeriidae) in experimentally infected mice, Mus musculus. J. Protozool. 31: 392-398.

UPTON S.J., LINDSAY D.S., CURRENT W.L., BARNARD S.M. 1985: Mouse-to-mouse transmission of Caryospora simplex (Apicomplexa, Eimeriidae). J. Parasitol. 71: 395396.

UPTON S.J., SUNDERMANN C.A. 1990: Caryospora: biology. In: P.L. Long (Ed.), Coccidiosis in Man and Domestic Animals. CRC Press, Boca Raton, Florida, pp. 187204.

VOLF J., MODRÝ D., KOUDELA B. 2001: Experimental transmission of Caryospora kutzeri (Apicomplexa: Eimeriidae) by rodent hosts. Folia Parasitol. 48: 11-14.

WACHA R.S., CHRISTIANSEN J.L. 1982: Development of Caryospora bigenetica n. sp. (Apicomplexa, Eimeriidae) in rattlesnakes and laboratory mice. J. Protozool. 29: 272278. 